1

2

3

4

5 Francisco Javier Villaamil ${ }^{1}$, Ignacio Arnaiz ${ }^{2}$, Alberto Allepuz ${ }^{3}$, Mikel Molins ${ }^{4}$,

6 Mercedes Lázaro5; Bibiana Benavides ${ }^{3}$, Sebastián Jesús Moya ${ }^{3}$, Jordi Casal $^{3}$, Eduardo

7 Yus $^{6}$, Francisco Javier Diéguez ${ }^{7, *}$

8

9

10

11

12

13

14

15

\section{A survey of biosecurity measures applied on dairy cattle farms in}

Spain

${ }^{1}$ Veterinary practitioner, A Coruña, Spain

${ }^{2}$ Animal Health and Production Laboratory of Galicia. Mabegondo, A Coruña, Spain

${ }^{3}$ Department of Health and Anatomy Animal, Universitat Autònoma de Barcelona (UAB), Barcelona, Spain.

${ }^{4}$ Animal Health Laboratory of Catalonia, Lleida, Spain

${ }^{5}$ Dairy Interprofessional Laboratory of Catalonia, Cabrils, Barcelona, Spain

${ }^{6}$ Institute of Food Analysis and Research, Universidade de Santiago de Compostela, Lugo, Spain

${ }^{7}$ Department of Anatomy, Animal Production and Clinical Veterinary Sciences, Universidade de Santiago de Compostela (USC), Lugo, Spain. 
bioRxiv preprint doi: https://doi.org/10.1101/673996; this version posted June 17, 2019. The copyright holder for this preprint (which was not certified by peer review) is the author/funder, who has granted bioRxiv a license to display the preprint in perpetuity. It is made available under aCC-BY 4.0 International license.

27

$28 *$ Corresponding author

29 E-mail: franciscojavier.dieguez@usc.es (FJD) 


\section{Abstract}

32 Attention to biosecurity has been highlighted as the most important measure to reduce and prevent the introduction of diseases to farms. There is little published information about the biosecurity of dairy cattle in Spain. We therefore aimed to assess and characterize the current application of biosecurity measures on dairy cattle farms in Spain, and relate these to bovine viral diarrhea and infectious bovine rhinotracheitis. From July 2017 to April 2018, data on biosecurity measures for 124 dairy herds were collected using a questionnaire. We also assessed the sanitary status of these farms (efficacy of measures implemented against both diseases using antibody ELISA. Data were analyzed descriptively, and using multiple correspondence analysis and a two-step cluster analysis. Measures to prevent disease introduction were often poorly implemented. Three main clusters of farms were identified: Clusters 1 and 2 included herds of small and intermediate sizes, respectively. These, particularly cluster 1 , showed the most deficiencies in the control of vehicles and visitors. However, individual purchases usually involved low numbers of animals, especially in cluster 2 , and animals were tested for bovine viral diarrhea and infectious bovine rhinotracheitis at their places of origin or on arrival at farms. Farms in clusters 1 and 2 were frequently under voluntary control programs. Cluster 3 had the largest herd sizes, with somewhat better biosecurity control of vehicles and visitors. However, farms in this cluster also purchased the most animals, sometimes without testing, and hired external workers most often. Farms in cluster 1 showed the best sanitary level, followed by clusters 2 and 3. Collecting data such as these is an important first step to identification of biosecurity shortcomings, and to structuring of adequate follow-up to ensure that measures are

54 implemented correctly on farms in Spain. 


\section{Introduction}

56 Infectious agents that affect livestock may be transmitted by various routes such as live

57 infected animals, trucks and other vehicles, people, aerosols, fomites, or wildlife or

58 insect vectors. Thereby, prevention through biosecurity is the most cost-effective

59 protection (1).

60

61

62

Within the context of animal production, biosecurity is defined as management activities that reduce the opportunities for infectious agents to gain access to, or spread within, a production unit (2).Thus, it has two main components: external and internal biosecurity. External biosecurity entails preventive measures and risk reduction strategies designed to avoid the introduction of pathogenic infections (hazards), whereas internal biosecurity entails measures to limit within-farm transmission of infectious hazards between animals $(\underline{3})$.

The importance of biosecurity is highlighted in the European Union health strategy. From 2007 onwards, the EU embraced a new motto as part of its Animal Health Strategy: "prevention is better than cure", now implemented by the European Commission. The aim was to focus on preventive measures, disease surveillance, controls, and research to reduce the incidence of animal diseases and minimize the impact of outbreaks (ㄴ)

The putative benefits of undertaking biosecurity for disease prevention and/or control include improvements in production efficiency (hence greater profits), animal welfare, immune responses to vaccines, and job satisfaction for producers, herd health professionals, and other agricultural workers (ㅁ). In addition, in pig herds, a link between biosecurity and antimicrobial treatment-related criteria has been demonstrated and quantified (ㅁ). 
Despite these benefits, implementation of biosecurity on dairy cattle farms is often sub-optimal, and poor or inappropriate knowledge transfer is often cited as a potential cause of disease spread (). The main limitations and strengths of the biosecurity measures applied in dairy cattle farms have been studied recently in several countries $(\underline{7-10})$, as a preparatory step to develop greater awareness of the importance of each measure and the factors that might restrict its application. In Spain, despite the economic importance of milk production in some regions, current biosecurity practices on dairy farms have not been studied empirically although a recent study assessed perceptions and practices applied by rural veterinarians $(\underline{11})$. bovine viral diarrhea (BVD) and infectious bovine rhinotracheitis (IBR) is highly variable among Spanish regions. In some, the situation is unknown and the approach to outbreaks depends mainly on the actions of individual veterinarians and farmers. In others, mainly in the northwest, voluntary programs were established some time ago, and now involve a large proportion of the cattle population (12). 1 (BoHV-1) are highly contagious diseases of economic and trade importance for the livestock industry worldwide. They can cause serious economic losses, with pathogenic effects including reduced milk yield, infertility, abortion, respiratory disease, and an increase in opportunistic infections such as calf pneumonia and scours $(\underline{13}, \underline{14})$. For all these reasons, several European countries have implemented official voluntary or compulsory programs to eradicate both diseases $(\underline{15}, \underline{16})$. application of biosecurity measures on dairy cattle farms in Spain, and the relationship of these to BVD and IBR. 


\section{Materials and methods}

\section{Area description and herds surveyed}

106 We conducted our study in two Autonomous Communities (AC) of Spain: Galicia

107 (NW), and Catalonia (NE). Galicia is the main dairy cattle area of the country, with $55 \%$ of the farms and $38 \%$ of the milk production. The mean herd size per farm is 43 cows, lower than the national average of 59.3, and farms are still predominantly family owned and managed. This region is representative of the production type prevailing in the NW and Cantabric area of the country. In contrasts, farms in Catalonia have a mean herd size of 144 cows, with $4 \%$ of the farms nationally yielding $11 \%$ of the milk production (17). The farm typology in this region could be considered representative of the rest of Spain. 1todairy cattle herds. For farm selection, the project was presented to the veterinarians responsible for health management in the main dairy cattle areas from both regions. Subsequently, together with the veterinarians, the project was communicated to farmers and those interested in participation were enrolled in the study.

\section{Biosecurity questionnaire}

123 Data were obtained using a questionnaire which was completed during personal interviews with farmers and the veterinarian responsible for health management of each farm. Farms were visited between July 2017 and April 2018. 

and neighborhood (i.e. other ruminant farms in a $1 \mathrm{~km}$ radius); III) movements and types of vehicles and equipment (for live and dead animal transport, manure, slurry and feeding vehicles, machinery or materials) and biosecurity-related measures (e.g. vehicles may enter inside the farm perimeter, vehicles may enter with other animals.) and IV) visitors and staff (e.g. external workers, frequency of professional or nonprofessional visitors that may contact animals, use of protective clothing).

\section{Health status}

The BVDV and BoHV-1 sanitary status of the farms was determined using antibody

ELISA, taking into consideration the fact that farms that applied vaccines used inactivated vaccines in case of BVDV and marker vaccines (live or inactivated) in case of BoHV-1.

For BVDV, antibodies against the p80 antigen were determined using a commercial blocking ELISA(BVD p80 Ab, IDEXX laboratories, the Netherlands), since the antibodies of animals vaccinated with inactivated vaccines react mainly with structural proteins rather than the p125 or p80 antigens (18). Additionally, in Galicia, when tested samples indicated possible persistent infection (PI) in an animal (i.e., when

147 a positive result was obtained fora young heifer), this was confirmed by antigen capture 
on detection of the $E^{\text {rns }}$ viral protein. Two samples positive for BVDV from the same animal taken 3-4 weeks apart were considered to confirm persistent infection.

For the case of BoHV-1, two different tests were used depending on whether vaccines were used on the herd (IDEXX IBR gE antibody, IDEXX Laboratories; the Netherlands) or not (IDEXX IBR gB antibody, IDEXX Laboratories; the Netherlands). All analyses were performed following the recommendations of the manufacturer.

Using the results of these tests, three different BoHV-1 and BVDV farm profiles were established: (1) farms with recent or active infection (BVDV seropositivity in heifers from 9 to 24 months born on the farm and/or PI confirmed), (2) farms with seropositive adult animals but all rearing heifers (9-24 month) seronegative, or(3) free farms (all animals tested seronegative).

\section{Statistical analysis}

All statistical tests were performed with SPSS 15.0. Initially, the frequencies of the different BoHV-1 and BVDV profiles and biosecurity measures were analyzed.

dairy cattle farms from Spain, a multiple correspondence analysis (MCA) was performed. MCA aims to reduce a set of possibly correlated variables (including all the biosecurity variables and the sanitary status of the farms) to a smaller group of linearly uncorrelated dimensions. We set the number of dimensions to two, to facilitate twodimensional graphical representation. The position of the full set of categories for each investigated variable (category-points) on the MCA graph is the basis for revealing relationships among variables: variable categories with a similar profile tend to group 
together, whereas negatively correlated categories are located on opposite sides of the graph. In addition, a two-step cluster analysis (TSCA) was performed to identify clusters of farmers with similar biosecurity levels and BVDV and BoHV-1 profiles. For this analysis, the frequencies of entry of animals, vehicles, and visits (collected as numerical values) were processed as categorical (4 categories based on the quartiles of the variables), but finally were transferred to the results as mean and median frequencies of entry.

\section{Results}

BVDV and BoHV-1 profiles of the124 farms are summarized in Table 1. The serologically free farm category represented similar proportion of the total for both viruses $(50 \%$ and $44.3 \%$ for BoHV-1 and $\mathrm{BVDV}$, respectively). However, the proportion of farms categorized as recent/active infection was much higher for BVDV (36.1\% versus $10.7 \%$ ). Thirty-seven of 124 farms used inactivated vaccines against BVDV, whereas the remainder did not vaccinate; 33 used marker vaccines for BoHV-1 whereas the remainder did not vaccinate.

Table 1. BVDV and BHV-1 sanitary status of 124 farms in Spain

\begin{tabular}{|c|c|c|}
\hline & Sanitary status & N (\%) \\
\hline \multirow{2}{*}{ BoHV-1 } & Recent/active infection & $13(10.7 \%)$ \\
\cline { 2 - 3 } & Seropositive animals (but rearing heifers free) & $48(39.3 \%)$ \\
\cline { 2 - 3 } & Free farm & $63(50.0 \%)$ \\
\hline \multirow{2}{*}{ BVDV } & Recent/active infection & $44(36.1 \%)$ \\
\cline { 2 - 3 } & Seropositive animals (but rearing heifers free) & $24(19.7 \%)$ \\
\hline
\end{tabular}


Table 2 describes biosecurity measures related to animal movements and possible contact with other domestic ruminants. For most farms, the risk of introduction

192 of diseases through the purchase of animals (heifers or cows) was presumably

193 negligible, as most reared their own replacements. Farms that purchased cattle (46/124,

$19437.1 \%$ ) had a low mean frequency of introductions (5.2 purchased animals/year).

195 However, it is noteworthy that 11/46 (23.9\%) farms purchased animals without any 196 testing, 39/46 farms (84.8\%) purchased cattle that could contact other cattle during 197 transport, and most farms lacked adequate quarantine facilities. Animal movement to 198 cattle fairs or competitions was a possible pathway of disease transmission for only $1997 / 124$ farms $(5.7 \%)$, but it is noteworthy that nearly all farms reported that animals 200 returned to the farm without any quarantine. Movements to pasture were much more 201 frequent: 54/124 farms (43.6\%) reported this type of movement, and half of these 202 reported the possibility of contact with other domestic ruminants at the pasture.

203 Moreover, most farms had other cattle or sheep/goat farms within a $1 \mathrm{~km}$ radius.

204 Table 2. Biosecurity measures related to purchase of cattle, or possible contact 205 with other ruminants, for 124 farms in Spain

\begin{tabular}{|c|c|c|}
\hline \multirow{2}{*}{ Purchase of animals (heifers/cows) } & No $(\%)$ & $78(62.9 \%)$ \\
\cline { 2 - 3 } & Yes (sanitary status assessed at origin) & $18(14.5 \%)$ \\
\cline { 2 - 3 } & Yes (sanitary status assessed on arrival) & $17(13.7 \%)$ \\
\cline { 2 - 3 } & Yes, without testing & $11(8.9 \%)$ \\
\hline $\begin{array}{c}\text { Average (median) frequency of heifers } \\
\text { or cows purchased/year, when }\end{array}$ & $5.25(3)$ & \\
\hline
\end{tabular}




\begin{tabular}{|c|c|c|}
\hline applicable & & \\
\hline \multirow[t]{3}{*}{ Transport of purchased heifers/cows } & $\begin{array}{l}\text { Cannot contact other ruminants during } \\
\text { transport }\end{array}$ & $39(84.8 \%)$ \\
\hline & Can contact other ruminants & $7(15.2 \%)$ \\
\hline & Not applicable & 78 \\
\hline \multirow[t]{2}{*}{ Adequate quarantine facilities } & Yes & $4(3.2 \%)$ \\
\hline & No & $120(96.8 \%)$ \\
\hline \multirow[t]{2}{*}{ External rearing } & No & $112(90.2 \%)$ \\
\hline & Yes & $12(9.8 \%)$ \\
\hline \multirow{3}{*}{$\begin{array}{l}\text { Sanitary plan in the external rearing } \\
\text { farm }\end{array}$} & Yes & $6(50.0 \%)$ \\
\hline & No & $6(50.0 \%)$ \\
\hline & Not applicable & 112 \\
\hline \multirow[t]{2}{*}{ Cattle farms within $1 \mathrm{~km}$} & No & $16(12.9 \%)$ \\
\hline & Yes & $108(87.1 \%)$ \\
\hline \multirow[t]{2}{*}{ Sheep/goat farms within 1 km } & No & $81(65.3 \%)$ \\
\hline & Yes & $43(34.7 \%)$ \\
\hline \multirow[t]{2}{*}{ Sheep/goats in the farm } & No & $113(92.6 \%)$ \\
\hline & Yes & $11(7.4 \%)$ \\
\hline \multirow[t]{3}{*}{ Participation in cattle fairs/competitions } & No & $117(94.3 \%)$ \\
\hline & Yes (no return) & $1(0.8 \%)$ \\
\hline & Yes (possible return) & $6(4.9 \%)$ \\
\hline \multirow[t]{2}{*}{ Pasture } & No & $70(56.4 \%)$ \\
\hline & Yes, no contact with other ruminants & $28(22.6 \%)$ \\
\hline
\end{tabular}


Yes, possible contact with other ruminants

207 Vehicles visiting the farms represented an infection risk for most of the surveyed

208 farms, because nearly all vehicles entered inside the perimeter of all farms (Table 3).

209 The most frequently entering vehicles were feeder wagons, followed by those collecting

210 animals for slaughter, or calves for feedlot. Moreover, in most farms (92.6\%), vehicles

211 in the latter two categories were permitted to arrive carrying domestic ruminants from

212 other farms. Several farms shared machinery or other vehicles, such as manure or slurry

213 vehicles, with other cattle farms.

214 Table 3. Biosecurity measures related to vehicles and equipment in 124 farms in

215 Spain

\begin{tabular}{|c|c|c|}
\hline & & $\mathbf{N}(\%)$ \\
\hline \multirow[t]{2}{*}{ Shared feeder wagon } & No & $48(38.7 \%)$ \\
\hline & Yes & $76(61.3 \%)$ \\
\hline $\begin{array}{l}\text { Average (median) number of entries of the feeder wagon per week, } \\
\text { when shared }\end{array}$ & \multicolumn{2}{|c|}{$7.1(7)$} \\
\hline \multirow[t]{2}{*}{ Shared machinery } & No & $60(47.5 \%)$ \\
\hline & Yes & $64(52.5 \%)$ \\
\hline \multirow[t]{2}{*}{ Shared manure vehicle } & No & $103(80.1 \%)$ \\
\hline & Yes & $21(18.9 \%)$ \\
\hline $\begin{array}{l}\text { Average (median) number of entries of the manure vehicle per month, } \\
\text { when shared }\end{array}$ & \multicolumn{2}{|c|}{$0.39(0.17)$} \\
\hline
\end{tabular}




\begin{tabular}{|c|c|c|}
\hline \multirow{2}{*}{$\begin{array}{l}\text { Shared materials (ear tag applicators, calving materials, cleaning } \\
\text { materials or others) }\end{array}$} & No & $100(80.3 \%)$ \\
\hline & Yes & $24(19.7 \%)$ \\
\hline \multirow[t]{2}{*}{ Shared slurry vehicle } & No & $82(66.2 \%)$ \\
\hline & Yes & $42(33.8 \%)$ \\
\hline $\begin{array}{l}\text { Average (median) number of entries of the slurry vehicle per month } \\
\text { (when shared) }\end{array}$ & \multicolumn{2}{|c|}{$0.33(0.08)$} \\
\hline \multirow[t]{2}{*}{ Carcass deposit area } & Outside farm perimeter & $27(20.5 \%)$ \\
\hline & Inside farm perimeter & $97(79.5 \%)$ \\
\hline $\begin{array}{l}\text { Average (median) number of entries of the carcass vehicle per month } \\
\text { inside the farm perimeter (when applicable) }\end{array}$ & \multicolumn{2}{|c|}{$0.34(0.17)$} \\
\hline \multirow[t]{3}{*}{ Vehicle (slaughter/feedlot) may arrive carrying animals from outside } & No & $5(3.3 \%)$ \\
\hline & Not know & $5(4.1 \%)$ \\
\hline & Yes & $114(92.6 \%)$ \\
\hline \multirow[t]{2}{*}{ Vehicles (slaughter/feedlot) may enter inside farm perimeter } & No & $6(4.9 \%)$ \\
\hline & Yes & $118(95.1 \%)$ \\
\hline $\begin{array}{l}\text { Average (median) number of entries of the slaughter/feedlot vehicle per } \\
\text { month inside farm perimeter }\end{array}$ & \multicolumn{2}{|l|}{$2.6(2)$} \\
\hline
\end{tabular}

217 Control of visits and staff also showed room for improvement (Table 4). Most

218 farms had no perimeter fences (89.3\%), and visitors' parking was usually inside the

219 farm perimeter (96.7\%). Farms also commonly received visitors who, without

220 protective clothing, had contact with the animals (92.6\%).

221 Table 4. Biosecurity measures related to visitors and staff in 124 farms in Spain 


\begin{tabular}{|c|c|c|}
\hline & & $\mathbf{N}(\%)$ \\
\hline \multirow[t]{3}{*}{ (External) employees } & No & $68(55.7 \%)$ \\
\hline & $\begin{array}{l}\text { Yes, but do not work in } \\
\text { other farms }\end{array}$ & $44(34.4 \%)$ \\
\hline & $\begin{array}{l}\text { Yes, and they work in other } \\
\text { farms }\end{array}$ & $12(9.8 \%)$ \\
\hline \multirow[t]{3}{*}{ Perimeter fence } & Yes, always close & $5(4.1 \%)$ \\
\hline & Yes, not always close & $8(6.6 \%)$ \\
\hline & No & $111(89.3 \%)$ \\
\hline \multirow[t]{2}{*}{ Vehicle parking for visitors } & Outside farm perimeter & $4(3.3 \%)$ \\
\hline & Inside farm perimeter & $120(96.7 \%)$ \\
\hline $\begin{array}{l}\text { Average (median) number of visitors per } \\
\text { month that can contact animals }\end{array}$ & \multicolumn{2}{|l|}{$7.2(5)$} \\
\hline \multirow[t]{2}{*}{ Visitors use protective clothing } & Yes & $9(7.4 \%)$ \\
\hline & No & $115(92.6 \%)$ \\
\hline
\end{tabular}
and health status among the 124 farms. The percentage of variance explained by the first dimension was $24.7 \%$, and for the second dimension was $14.2 \%$. scores obtained from the MCA, together with the solutions of the TSCA, are presented in Fig 2. Three main clusters were formed that included 122 out of the 124 herds. S1

229 Table (within-cluster percentages) shows how each sanitary category or biosecurity variable is split within each cluster. 
232 Fig 1. Joint MCA plot of category points for the different biosecurity measures, and BVDV/BoHV-1 profiles resulted from multiple correspondence analysis. Frequencies of cattle purchases, and entries of vehicles and visitors, each with 4 categories based on the quartiles of these frequencies, are not shown.

Fig 2. Object scores of the multiple correspondent analysis, and two-step cluster solution identifying 3 main clusters including 122 of the 124 study herds; the remaining 2 are shown in white in the center of the chart.

Cluster $1(n=62)$ comprised herds located mainly in the upper left quadrant of the MCA chart. All these herds were from Galicia, with low mean herd size (51 cows). These farms were most frequently BVDV and BoHV-1-free. the farm of origin or on arrival. However, they did not have adequate quarantine facilities. This cluster was the one that most often used external rearing farms. Grazing was observed more frequently than in the other clusters, including possible contact between the farm's cattle and ruminants from other farms. In addition, these herds were located in high-density cattle areas, with most located within $1 \mathrm{~km}$ of other cattle farms.

This cluster was also the one that most frequently shared machinery and materials with other farms. mostly lacked structures such as perimeter fencing or outdoor parking. Interestingly, these farms received numerous visitors despite their small size. Although the use of 
suitable protective clothing emerged as deficient in the entire sample of farms, it was especially inadequate in this cluster.

Cluster $2(\mathrm{n}=31)$ included herds also from Galicia, often of intermediate size (mean 63 cows). From the sanitary point of view, these farms often had seropositive animals but without evidence of recent or active infection.

These farms purchased animals less frequently than did those in other clusters. When they did so, purchases often entailed few animals that were tested, usually at their origin, against BVDV and BoHV-1. This was also the cluster with more control over the transport of purchased animals, avoiding contact with external cattle during transport. As in the previous cluster, these farms were located in high-density cattle areas, and most also had other small ruminant farms within $1 \mathrm{~km}$.

Structures such as perimeter fencing or outdoor parking for visitors were also scarce in cluster 2 farms. Numbers of external workers were intermediate between those for clusters 1 and 3 . Although cluster 2 farms received less visitors, the use of adequate protective clothing was still scarce.

Cluster $3(n=29)$ comprised all herds from Catalonia, with the largest herds (mean 122 cows). This cluster had the highest proportions of active/recent infections with BVDV and BoHV-1.

Purchase of replacement animals was most common in cluster 3 , and the number of purchased animals was usually high. Notably, the 11 farms that purchased animals without any testing were included in this cluster. Although infrequent, it was also the cluster with the highest frequency of participation in cattle fairs or contest.

Farms in this cluster shared machinery or materials less frequently than did the smaller farms in clusters 1 and 2,but manure vehicles were shared much more often than 
in the other two clusters. The frequency of entry of manure and slurry vehicles was also

highest in cluster 3 farms, but shared use of feeder wagons was less frequently observed than in the other two clusters.

but nonetheless more frequent than in the other clusters. All cluster 3 farms employed external workers who often worked also on other farms. The use of protective clothing by visitors was somewhat more common in this cluster.

\section{Discussion}

Spain is the eighth-largest dairy producer in the E.U., being responsible for $4.5 \%$ of the milk produced (19). Despite this, published information about biosecurity on Spanish dairy cattle farms is very scarce, and official or private initiatives for the implementation of biosecurity programs in this livestock sector are few.

Our study showed important short comings in the application of biosecurity measures in this sector, particularly highlighting room for improvement of such measures controlling various potential routes of disease introduction. Fortunately, most farms do not purchase animals, but among those who do there are still farms that do not cattle during transport process. Several types of vehicles, especially feeding vehicles,

297 frequently enter farms. Policies related to visitors should also be improved: for example, nearly $93 \%$ of visitors that have contact with the animals do not use protective clothing. on dairy farms elsewhere in Europe $(\underline{7}, \underline{11}, \underline{20})$. The implementation of biosecurity plans 
on dairy farms is voluntary in almost all countries, with the exception of larger dairy

302 farms in Denmark (21). Reg. (EU) No. 429/2016, which shall apply from 2021 and will

affect EU animal health legislation, recognizes and addresses the importance of

biosecurity (22). Therefore, farmers need to be motivated both to change existing behaviors, and to implement effective biosecurity practices to reduce the risk of disease introduction $(\underline{23})$.

Our MCA and TSCA analyses show that there are different farm-typologies in relation to the implementation of biosecurity measures and their health status. challenge to investment in infrastructure such as perimeter fencing or parking. For the same reason, such farms may frequently be forced to share machinery or materials. visitors who come into contact with animals, both professional (veterinarians, technicians, etc.) and non-professional (neighboring farmers, etc.). Small farms more frequently require timely collaboration from neighboring farmers, for example, in the case of a calving, or receive courtesy visits from them, since such farms function with close links between the farm and the farmer's own house, as has been described elsewhere (24). Despite the abovementioned lack of biosecurity measures, the proportion of such farms with recent/active BoHV-1 or BVDV infection was very low, possibly because of several factors. these are voluntary, and executed only in some AC. In Galicia and other regions in the north-west and the Cantabric area, such programs are conducted mainly through 

purchased animals against BVDV and BoHV-1using established protocols (르). In the dairy cattle sector, the presence of the ADSG has increased awareness of the importance of incorporation of biosecurity controls into farming practices. Many farms that do not belong to ADSG now also practice such controls. Purchased cattle are considered to be the main risk factor for disease entry to dairy farms $(\underline{3}, \underline{26}-\underline{29})$.

In contrast, cluster 3 included the largest herds in our study, located in Catalonia. Herd size has been previously described as a cluster variable for several biosecurity risks such as increased purchase of animals, increased visitors (veterinary practitioners, technicians), and the presence of external workers, all of which will increase the likelihood of disease introduction and maintenance ( $\underline{30})$. Cluster 3 farms in our study met all these characteristics, and, in addition, sometimes introduced animals without testing. Thus, although some facilities (i.e. perimeter fencing, outdoor parking) or biosecurity measures (use of protective clothing by visitors or scarce use of shared material or equipment) are more frequent in these farms, the cluster 3 showed the poorest sanitary level.

On the other hand, when comparing clusters 2 and 1, we observed that farms that purchase animals are somewhat more numerous in cluster 1 , so herd size and number of animal purchases are not directly related in these two clusters. The smallest farms sometimes combine dairy production with other professional activities, using dairy 348 farming to supplement family income ( $\underline{31})$. Thus, the lack of labor and even facilities 349 for rearing heifers could explain the higher frequency of purchases than larger farms in 
cluster 2. Cluster 1 farms also use external rearing farms more frequently than do farms in cluster 2.

The most frequent sanitary status for cluster 2 was the presence of seropositive animals without evidence of recent or active infection. BVDV and border disease virus control programs, and act only in cases of clinical outbreaks. Thereby, the risk they could pose is unknown. us to explain the questions clearly, and to control for the bias related to social desirability response; in addition, the veterinarian responsible for the sanitary program of the farm was present. However, it is important to keep in mind that farmers enrolled voluntarily in the study, and therefore our results cannot be extrapolated directly to all dairy farms in Spain due to possible selection bias. Farmers more concerned with biosecurity might have decided to participate in the project, resulting in overrepresentation of farms with relatively good implementation of biosecurity measures in our sample. Additionally, the existence of voluntary ADSG BoHV-1 and BVDV control programs in Galicia but not in other regions may have reduced the representative value of our sample. provided a comprehensive overview of the main biosecurity shortcomings in the dairy 
sector of Spain. Such data should be useful to focus future training and to improve risk reduction strategies in this economically important industry.

\section{Acknowledgements}

The authors want to thank all the farmers and veterinarians involved in the study. This research was supported by a project from the Ministry of Science and Innovation of Spain (AGL2016-77269-C2-2-R).

\section{References}

1. Van Schaik G, Nielen M, Dijkhuizen AA. An economic model for on-farm decision support of management to prevent infectious disease introduction into dairy farms. Prev Vet Med. Elsevier Science B.V.; 2001; 51:289-305.doi:

3. Mee JF, Geraghty T, O'Neill R, More SJ. Bioexclusion of diseases from dairy and beef farms: Risks of introducing infectious agents and risk reduction Vet $\mathrm{J}$. Elsevier Ltd; 2012; 194: 143-150. doi: $10.1016 /$ j.tvj1.2012.07.001 PMID: $\underline{23103219}$

4. European Commission.A new Animal Health Strategy for the European Union (2007-2013) where "Prevention is better than cure". Available: http://ec.europa.eu/food/animal/diseases/strategy/docs/animal_health_strategy_e $\underline{\text { n.pdf }}$ 
5. Brennan ML, Christley RM. Biosecurity on cattle farms: a study in north-west England. PLoS One. 2012; 7(1): e28139. doi: 10.1371/journal.pone.0028139 PMID: 22235244

6. Laanen M, Persoons D, Ribbens S, de Jong E, Callens B, Strubbe M et al. Relationship between biosecurity and production/antimicrobial treatment characteristics in pig herds. Vet. J. Elsevier Ltd; 2013; 198: 508-12.

7. Sayers RG, Good M, Sayers, GP. A survey of biosecurity-related practices, opinions and communications across dairy farm veterinarians and advisors. Vet J. Elsevier Ltd; 2014;200: 261-269.doi: 10.1016/j.tvj1.2014.02.010 PMID: $\underline{24679454}$

8. Sahlström L, Virtanen T, Kyyrö J, Lyytikäinen T. Biosecurity on Finnish cattle, pig and sheep farms-results from a questionnaire. Prev Vet Med. Elsevier B.V.; 2014; 117: 59-67.doi: 10.1016/j.prevetmed.2014.07.004 PMID:25147126

9. Sarrazin S, Cay AB, Laureyns J, Dewulf J. A survey on biosecurity and

10. Kuster K, Cousin ME, Jemmi T, Schüpbach-Regula G, Magouras I. Expert management practices in selected Belgian cattle farms. Prev Vet Med. Elsevier B.V.;2014; 117: 129-139.doi: $\quad$ 10.1016/j.prevetmed.2014.07.004

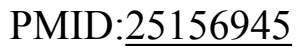
opinion on the perceived effectiveness and importance of on-farm biosecurity measures for cattle and swine farms in Switzerland. PloS One, 2015; 10(12):

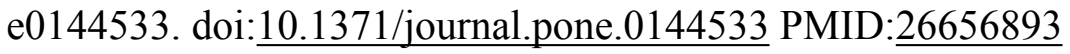


11. Renault V, Humblet MF, Moons V, Bosquet G, Gauthier B, Cebrián LM et al. Rural veterinarian's perception and practices in terms of biosecurity across three European countries. Transbound Emerg Dis. 2018; 65:e183-e193. doi: $\underline{\text { 10.1111/tbed.12719 PMID:28940807 }}$

12. Arnaiz I, Eiras C, Carnero MI, Rubinos V, Calavia PM, Cortón ME et al. 15 años de programa de control voluntario frente al IBR en Galicia: situación ante $\mathrm{u}$ programa de erradicación. XXIII Congreso Internacional de Medicina Bovina Anembe; Vigo, 2018. pp 348-349

13. Can MF, Ataseven VS, Yalçin C. Estimation of production and reproductive performance losses in dairy cattle due to bovine herpesvirus 1 (BoHV1) infection. Vet Arhiv. 2016; 86: 499-513.

14. Richter V, Lebl K, Baumgartner W, Obritzhauser W, Käsbohrer A, Pinior B. A $\underline{\text { 10.1016/j.tvji.2017.01.005 PMID:28190502 }}$

15. European Commission. Commission Implementing Decision (EU) 2017/486 of 17 March 2017 amending Annexes I and II to Decision 2004/558/EC. Available: https://eurlex.europa.eu/legalcontent/EN/TXT/?qid=1556212590594\&uri=CELEX:32017 $\underline{\mathrm{D} 0486}$ systematic review of financial and economic assessments of bovine viral 
Med. Elsevier B.V.;2017; 137: 77-92.doi: 10.1016/j.prevetmed.2016.12.014

17. Ministerio de Agricultura y Pesca, Alimentación y Medio Ambiente (MAPAMA), 2018. Panel situación sector lácteo España. Available: http://www.mapama.gob.es/es/ganaderia/temas/produccion-y-mercadosganaderos/pizarraabril18 tcm30-444377.pdf.

18. Bolin SR, Ridpath JF. Range of viral neutralizing activity and molecular specificity of antibodies induced in cattle by inactivated bovine viral diarrhea

19. Eurostat. 2018. Milk and milk products statistic. Available: https://ec.europa.eu/eurostat/statisticsexplained/index.php/Milk_and_milk_product_statistics\#Milk_production opinion on the practicality and effectiveness of biosecurity measures on dairy farms in the United Kingdom using choice modeling. J Dairy Sci. Elsevier; 2016; 100: 2225-39.doi: 10.3168/jds.2016-11435PMID:28088420

21. Kristensen E, Jakobse, E. Danish dairy farmers' perception of biosecurity. Prev Vet Med. Elsevier $\quad$ B.V.; 2011; 99: 122-129.doi: 10.1016/j.prevetmed.2011.01.010 PMID:21345504

22. Regulation (EU) 2016/429 of the European Parliament and of the Council of 9 March 2016 on Transmissible Animal Diseases and Amending and Repealing Certain Acts in the Area of Animal Health (“Animal Health Law”). 
23. Truyers IGR, Mellor DJ, Norquay R, Gunn GJ, Ellis KA. The eradication programme for bovine viral diarrhoea virus (BVDV) in Orkney 2001-2008. Cattle Practice, 2011; 19: 47.

24. Moya S, Allepuz A, Benavides B, Tirado F, Espluga J, Casal $J$ et al. Veterinarios y granjeros: investigando experiencia y opiniones sobre la implementación de medidas de bioseguridad en granjas de leche. Congreso

25. Diario Oficial de Galicia (DOGA), 2017. ORDEN de 27 de diciembre de 2017 por la que se establecen las bases reguladoras de las ayudas a las entidades reconocidas como agrupaciones de defensa sanitaria ganaderas (ADSG) de Galicia y se convocan para el año 2018-2019. Available:

26. Presi P, Struchen R, Knight-Jones T, Scholl S, Heim D. Bovine viral diarrhea https://www.xunta.gal/dog/Publicados/2018/20180117/AnuncioG0426-271217$\underline{0003 \text { es.html }}$

28. Amelung S, Hartmann M, Haas L, Kreienbrock L. Factors associated with the (BVD) eradication in Switzerland-experiences of the first two years. Prev Vet Med. Elsevier B.V.; 2011;99: 112-121.doi: 10.1016/j.prevetmed.2011.01.012 PMID: $\underline{21371766}$

27. Veldhuis A, Santman-Berends I, Schauer B, Mars J, Waldeck F, Staubach C et al. Epidemiological performance and subsequent costs of different surveillance strategies to control bovine herpesvirus type 1 in dairy farms. Prev Vet Med. Elsevier B.V.; 2017; 139: 105-114.doi: 10.1016/j.prevetmed.2016.12.003 PMID:28122659 bovine viral diarrhoea (BVD) status in cattle herds in Northwest Germany. Vet 
Microbiol. Elsevier

B.V.; 2018;

216:

212-217. doi:

29. Bezerra NPC, Bezerra, DC, Santos HP, de Moraes Pereira H, Silva ALA. Risk factors analysis applied to antibodies to Bovine Herpesvirus Type 1, Bovine Viral Diarrhea Virus, Bovine Leukemia Virus and Brucella abortus among cattle: a cross-sectional study. Acta Vet Bras. 2019; 13: 5-12. doi: $\underline{10.21708 / a v b .2019 .13 .1 .7818}$

30. Sayers RG, Byrne N, O'Doherty E, Arkins S. Prevalence of exposure to bovine viral diarrhoea virus (BVDV) and bovine herpesvirus-1 (BoHV-1) in Irish dairy

31. Barbeito F, López C. Resultados técnico-económicos das explotacións de vacún de leite en Galicia. 1st ed. Xunta de Galicia.2011.

32. Eiras MC, Viña M, Fernández D, Martínez S, Diéguez FJ. Border disease-like clinical signs in sheep caused by a BVDV-2 type d. Vet Rec. 2017 Case Rep 5:

34. et al. Detection of bovine viral diarrhoea virus 2 as the cause of abortion outbreaks on commercial sheep flocks. Transbound Emerg Dis. 2017; 64:1926.doi: 


\section{Supporting information}

S1 Table. Composition of sanitary and biosecurity profiles within 3 clusters

obtained through a two-step cluster analysis 
bioRxiv preprint doi: https://doi.org/10.1101/673996; this version posted June 17, 2019. The copyright holder for this preprint (which was available under aCC-BY 4.0 International license.

Yes, but animals never return to farm

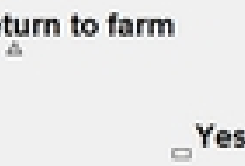

Not known

$\square^{\text {Yes }}$

Replacements can contact with other cattle during transport
Yes, some animal can return to farm

$$
\text { Yes, always close }
$$

\section{Outside farm perimeter}

\section{Yes}

Adequate quarantine facîties

(Eternal) employees

Bohv-1

Cattle tarms within $1 \mathrm{~km}$

External rearing

Participation in cattle tars/contest

Pasture

- Perimeter fence

Purchase of replacement hetersicows

Region

Santary plan in the external tearing farm

Shared machinery

Shared manute vehicle

Shared material

Shared slurry vehicle

Sheeplgoat farms within $1 \mathrm{~km}$

Sheepigoats in the herd

* Vehicle parking for visitors

- Vehicles transporting replacement heiferskcows

- Vehicles transporting animals for slaughter or for fattering can enter inside farm perimeter

Vehicles transporting animals for slaughter or for fattering can conse winh other arimals use protective clothing

Access to pasture

No Inside farm No perime

Yes, introduced without testing

contact with other ruminants) Replacements can not contact with other cattle during transpont

No $\odot$ No Free farm Yes

Yes (sanitary statusin origin) Recent/active infection Yes, and they work ${ }^{\mathrm{N} o}$ Catalonia

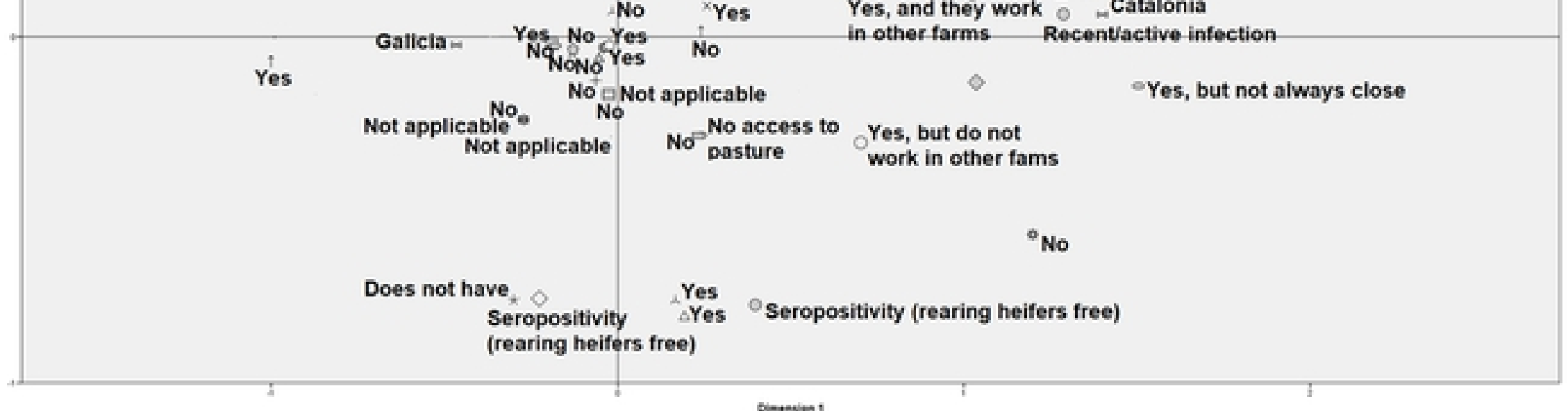




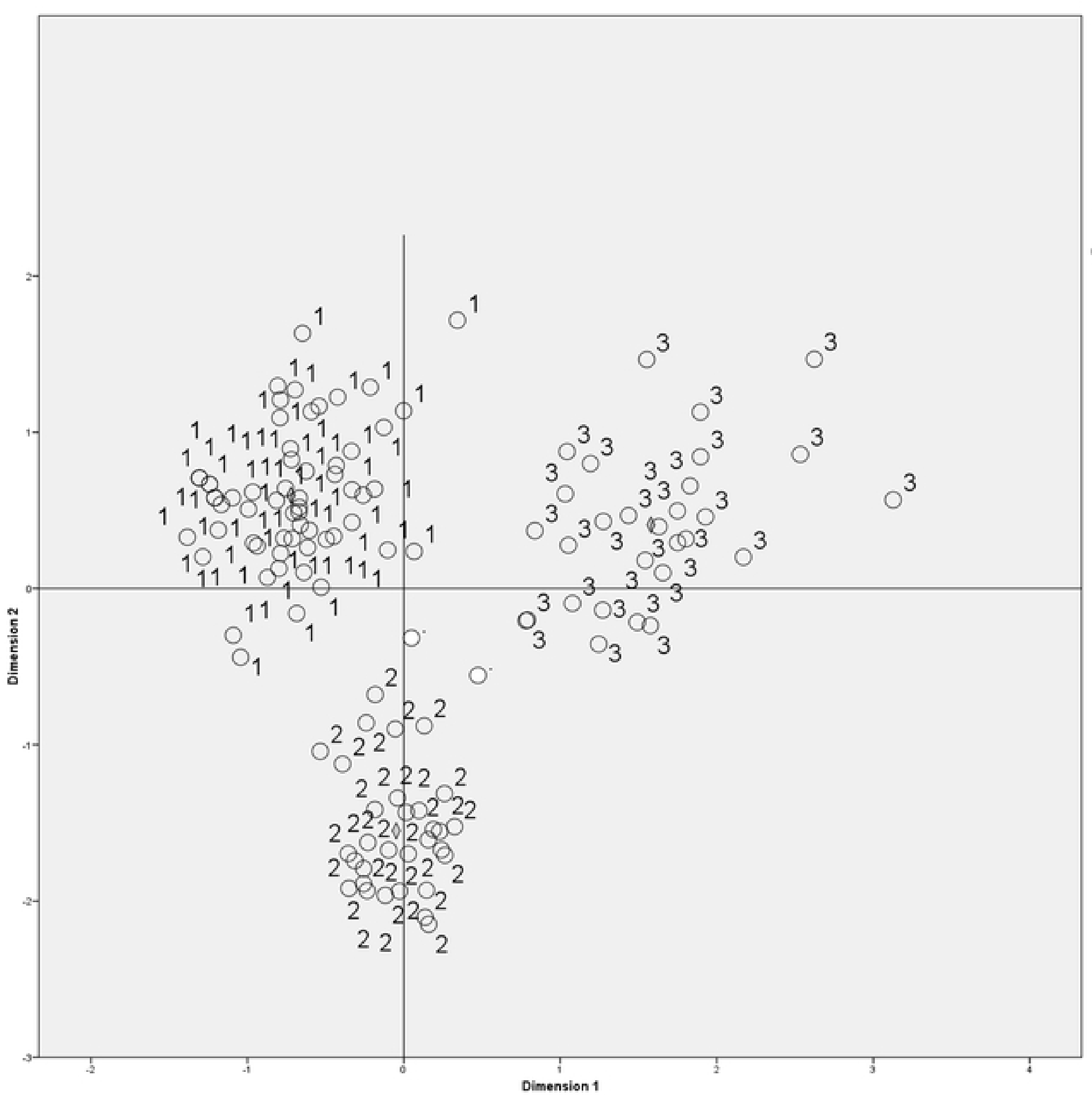

$\diamond$ Cluster centroids

Object scores

Fig2 